
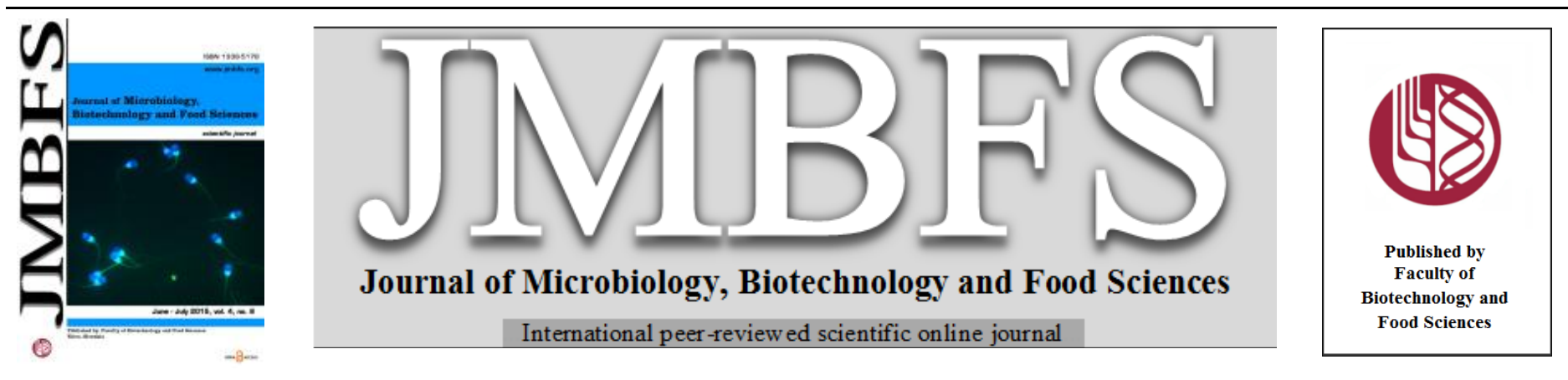

\title{
IMPACT OF FORTIFICATION WITH HONEY ON SOME PROPERTIES OF BIO-YOGHURT
}

\section{El-Tahra M. A. Ammar ${ }^{1}$; Magdy M. Ismail $*^{2}$; Abd El-Wahab E. Khalil ${ }^{1}$ and Mohamed Z. Eid ${ }^{2}$}

Address(es):

${ }^{1}$ Dairy Department, Faculty of Agriculture, Mansoura University, El-Mansoura, Egypt.

${ }^{2}$ Dairy Technology Department, Animal Production Research Institute, Agricultural Research Center, Dokki, Giza, Egypt.

*Corresponding author: abo-omar98@hotmail.com

doi: 10.15414/jmbfs.2015.4.6.503-508

\section{ARTICLE INFO}

Received 29. 9. 2014

Revised 31. 3. 2015

Accepted 31. 3. 2015

Published 1. 6. 2015

Regular article

open 2 access

\section{ABSTRACT}

The effect of supplementation with honey on yoghurt quality was studied. Five treatments of yoghurt were made from buffaloe's and cow's milk mixture (1:1). Control yoghurt was made using classic yoghurt culture, whereas the other four treatments were made by ABT culture and milk fortified with $0,2,4$, and $6 \%$ honey. Changes in rheological, chemical, microbial and organoleptic properties of yoghurt were monitored during refrigerated storage $\left(4^{\circ} \mathrm{C}\right)$ of yoghurt for $15 \mathrm{~d}$. Results showed that addition of honey to milk had no significant effect on ABT starter activity. A curd tension increased, whereas curd syneresis decreased in bio-yoghurt fortified with honey. Acidity, TS, WSN and TVFA contents of yoghurt supplemented with honey were higher than those of control. The contents of fat, ash and TN were similar in both. Addition of honey to yoghurt improved the viability of bifidobacteria. Bifidobacteria counts were similar to accepted threshold $\left(10^{6} \mathrm{cfu}^{-1}\right)$ for a probiotic effect. Also, addition of honey improved the body, texture and flavour of the yoghurt.

Keywords: Yoghurt, bifidobacteria, acidophilus, ABT, honey

\section{INTRODUCTION}

Yogurt is an important dairy product, particularly for consumers with lactose intolerance. Yogurt is considered a healthy food because it contains viable bacteria that are considered probiotics. LA and Bifidobacterium spp. also have been reported to increase immunity of the host animals (Hughes and Hoover, 1991), lower the level of harmful enzymes such as $\alpha$-glucosidase and $\alpha$ glucuronidase responsible for catalyzing the conversion of carcinogenic amines (Reddy, 1983) and are beneficial for improvement in lactose utilization in lactose malabsorbers (Shah, 1993). LA and bifidobacteria exert antagonistic effects on the growth of pathogens such as Staphylococcus aureus, Salmonella typhimurium, Yersinia enterocolitica and Clostridium perfringens (Ozbas and Aytac, 1995). Inoculums size of probiotic bacteria is an important and a key factor to ensure sufficient viable cells in the final yogurt. Therefore, it is imperative for $\mathrm{AB}$-yogurt manufacturers to ensure that at least one million viable cells of Lactobacillus acidophilus and bifidobacteria $\mathrm{g}^{-1}$ are present at the end of fermentation. If the required criterion is met, the number of probiotic bacteria should remain stable throughout the anticipated shelf life (Samona and Robinson, 1994).

On the other hand, the health benefits of honey have long been realized by humans to treat a variety of ailments. Besides its sugar composition, honey consists of a number of bioactive compounds such as phenolic compounds, flavonoids, carotenoid-like derivatives, organic acids, Maillard reaction products, catalase, ascorbic acid, and other compounds which function as antioxidants (Bogdanov et al., 2008). Several therapeutic and medicinal effects such as antibacterial, antimutagenic, antiproliferative, hepatoprotective, hypoglycemic, and antioxidant effects have been ascribed to honey through last years (Erejuwa et al., 2010 and Ghashm et al., 2010). Poorani et al. (2012) stated that honey, which is naturally available good product with high nutritive and medicinal value can be used preparing a bifidiogenic milk product by assessing the content of bifidus growth factor and further incorporation will give a valuable product. Therefore, the aim of this study was the possibility of increasing the nutritional and health values of bio-yoghurt by adding honey and also possibility of using honey as a prebiotics for yoghurt cultures.

\section{MATERIALS AND METHODS}

\section{Starter Cultures and Honey}

A commercial classic yoghurt starter containing Streptococcus thermophillus and Lactobacillus delbrueckii subsp. bulgaricus (1:1) and ABT-5 culture which consists of $S$. thermophiles, LA $+B$. bifidum (Chr. Hansen's Lab A/S Copenhagen, Denmark) were used. Starter cultures were in freeze-dried direct-tovat set form and stored at $-18^{\circ} \mathrm{C}$ until used. Honey was obtained from local market in Damiette Governorate, Egypt.

\section{Yoghurt Preparation}

Yoghurt treatments were prepared from fresh buffalo's and cow's milk mixture $1: 1$ (acidity $0.17 \%$, pH 6.61 , fat $5.1 \%$, TS $14.56 \%$ and total protein $3.87 \%$ ) in Dairy Laboratory of El-Serw Animal Production Research Station, Animal Production Research Institute, Agricultural Research Center. Five yoghurt treatments were made using classic yoghurt or ABT cultures. The first treatment was manufactured using classic yoghurt starter (control) whereas, treatments from two to five were made by ABT culture and milk fortified with $0,2,4$, and $6 \%$ honey, respectively. Fresh milk was tempered to $85^{\circ} \mathrm{C}$ for $15 \mathrm{~min}$, cooled to $40^{\circ} \mathrm{C}$, fortified with $0,2,4$ and $6 \%$ (wt/wt) honey, inoculated with cultures $(0.1 \mathrm{~g}$ $\mathrm{L}^{-1}$ of yoghurt mix), transferred to $100-\mathrm{ml}$ plastic cups, incubated at $40^{\circ} \mathrm{C}$ for fully coagulation, and stored at $4^{\circ} \mathrm{C}$ for 15 days. Yoghurt samples were analyzed when fresh and after 7 and 15 days of refrigerated storage. Three replicates of each treatment were conducted.

\section{Chemical Properties}

Total solids, fat, TN and ash contents of samples were determined according to (AOAC, 2000). Titratable acidity in terms of \% lactic acid was measured by titrating $10 \mathrm{~g}$ of sample mixed with $10 \mathrm{ml}$ of boiling water against $0.1 \mathrm{~N} \mathrm{NaOH}$ using phenolphthalein indicator to an end point of faint pink color (Parmar, 2003). $\mathrm{pH}$ of the sample was measured using a $\mathrm{pH}$ meter (Corning $\mathrm{pH} /$ ion analyzer 350, Corning, NY) after calibration with standard buffers ( $\mathrm{pH} 4.0$ and 7.0). Water soluble nitrogen (WSN) of yoghurt was estimated according to Ling (1963). Total volatile fatty acids (TVFA) were determined according to Kosikowiski (1978). 


\section{Rheological Properties}

The curd tension was determined using the method of Chandrasekhara $\boldsymbol{e t}$ al. (1957) whereas the curd syneresis was measured as given by Mehanna and Mehanna (1989). For test of coagulation time during yoghurt making, milk was inculcated with starters and incubated at $40^{\circ} \mathrm{C}$ then coagulation was noticed at 30 min intervals.

\section{Microbiological Analyses}

The count of bifidobacteria was determined according to Dinakar and Mistry (1994). A mixture of antibiotics, including $2 \mathrm{~g}$ of neomycin sulfate, $4 \mathrm{~g}$ of paromomycin sulfate, $0.3 \mathrm{~g}$ of nalidixic acid, and $60 \mathrm{~g}$ of lithium chloride (NPNL, Sigma Chemical Co.), was prepared in $1 \mathrm{~L}$ of distilled water, filtersterilized $(0.22 \mathrm{um})$, and stored at $4^{\circ} \mathrm{C}$ until use. The mixture of antibiotics $(5 \mathrm{ml}$ was added to $100 \mathrm{ml}$ of MRS agar medium. Cysteine-HC1 was added at the rate of $0.05 \%$ to decrease the redox potential of the medium. Plates were incubated at $37^{\circ} \mathrm{C}$ for 48 to $72 \mathrm{~h}$ under anaerobic condition.

\section{Organoleptic Analysis}

Samples of yoghurt were organoleptically scored by the staff of the El-Serw Animal Production Research Station. The score points were 50 for flavour, 35 for body and texture and 15 for colour and appearance, which give a total score of 100 points (El-Shazly et al., 2008).

\section{Statistical Analysis}

The obtained results were statistically analyzed using a software package (SAS 1991) based on analysis of variance. When F-test was significant, least significant difference (LSD) was calculated according to Duncan (1955) for the comparison between means. The data presented, in the tables, are the mean $( \pm$ standard deviation) of 3 experiments.

\section{RESULTS AND DISCUSSION}

\section{Changes in acidity during fermentation of yogurt}

For measurement of starter activity as affected by adding 2, 4 and $6 \%$ honey, the development of acidity values (as lactic acid percentages) of buffaloe's and cow's milk mixture inoculated with classic yoghurt and ABT cultures was determined at $30 \mathrm{~min}$ intervals till $180 \mathrm{~min}$. Results were tabulated in Table 1. As it is expected, a gradual increase of titratable acidity values in control and all samples was noticed during incubation for $180 \mathrm{~min}$. Acidity percentages of treatment A a the beginning and the end of incubation time were 0.15 and $0.52 \%$, respectively Both acidity ratios and the development of acidity rats within fermentation were a little bit higher in milk inoculated with classic starter (treatment A) than that of milk inoculated with ABT culture (treatment B). These outcomes are similar to that reported by Damin et al. (2008) who stated that milk fermented with Streptococcus thermophilus and Bifidobacterium lactis had the lowest post acidification. This behavior could be explained by the limited capacity of Bifidobacterium to produce organic acids at low temperatures (MattilaSandholm et al., 2002).

As shown from Table 1, the addition of various concentrations of honey to yoghurt milk had no significant effect on the acidity values during the $180 \mathrm{~min}$ of fermentation. After $180 \mathrm{~min}$ of incubation time, the acidity level was $0.48 \%$ for yoghurt made by ABT (treatment B) and lowered to $0.46,0.46$ and $0.44 \%$ for yoghurt fortified with 2,4 and $6 \%$ honey, respectively. These results are generally in harmony with those reported by Varga (2006) who found that the honey had no significant effect on $\mathrm{pH}$ and lactic acid levels of the final products.

\section{Changes in rheological properties of yoghurt}

The effect of using ABT culture and adding different levels of honey to buffaloe's and cow's milk mixture on coagulation time, curd tension and curd syneresis were presented in Table 2. The contribution of bifidobacteria with yoghurt culture has slightly changed the rheological attitude. Similar observation was reported by Hassan et al. (2003). Coagulation time of control treatment (A) was $3 \mathrm{~h}$ and slightly increased to $3.20 \mathrm{~h}$ as result of using ABT culture in yoghurt manufacture (treatment B). These results may be attributed to the slow acid production of ABT starter as compared with that of classic yoghurt. Saccaro et al. (2009) found that growth of probiotic strains, when grown singly or blends with yoghurt cultures affected the fermentation time and the rate of acidification. No significant differences were obtained in curd tension values between treatments A and B. The results of curd syneresis indicated that slight increasing in yoghurt syneresis was found in sample B.

Blending of honey with milk caused very slight increase in coagulation time of yoghurt (Table 2). Values of coagulation time of treatments B, C, D and E were $3.20,3.25,3.30$ and $3.30 \mathrm{~h}$, respectively. Because adding honey raised the total solids content of milk, the produced honey yoghurt had the highest values of curd tension comparing with control. De Jong (1978) stated that slight differences in moisture may cause major differences in rheological parameters. Also, Murad et al. (1998) and El-Nemer et al. (2003) showed that the hardness related to dry matter of the product. In contrast to our results Ayad, et al. (2010) stated that supplementation of yoghurt with honey and talbina (cooked barley bran flour) or with molasses and talbina decreased the hardness which could be due to the ability of polysaccharides in honey and molasses to bind with significant amount of free water. However the same authors also cleared that a positive relationship was found between hardness and TS\% which increased in honey or molasses yoghurt. Regarding of curd syneresis, bio-yoghurt fortified with honey possessed lower syneresis values than those of control.

\section{Changes in chemical composition of yoghurt}

The effect of using ABT culture and supplementation of yoghurt with 2, 4 and $6 \%$ honey on the titratable acidity (\% lactic acid), $\mathrm{pH}$, total solids (TS\%), Fat\% and Ash\% during the refrigerated storage was illustrated in Table 3. Using of ABT starter (treatment B) decreased titratable acidity ratios and increased $\mathrm{pH}$ values of fresh yoghurt and during storage period (15 days) as compared with that made by classic culture (treatment A). Acidity percentages of samples A and $\mathrm{B}$ at zero time were 0.79 and $0.62 \%$, respectively. These results agreed with Shihata and Shah (2002) and disagreed with Kehagias et al. (2006). Shihata and Shah (2002) reported that the ABT cultures are known to produce yoghurt with a fine, mild taste and low post acidification whereas Kehagias et al. (2006) stated that the addition of bifidobacteria to yoghurt starter increased acidity of yoghurt which attributed to the formation of both acetic and lactic acids by $B$. bifidum. In bio-yoghurt special attention should be given to avoid over acidification since this could affect the stability of bifidobacteria during storage period. No significant differences in TS, fat and ash contents between yoghurt made using classic or ABT cultures at zero time or within storage period. These results were confirmed by resulted of Ayad, et al. (2010) who stated that TS, $\mathrm{SNF}$, fat, F/DM and protein values in bifidus yoghurt-like products were not affected by bifidobacteria incorporation with yoghurt-like products.

Table 1 Effect of adding honey to buffaloe's and cow's milk mixture on activity of ABT culture (expressed as acidity percentage)

\begin{tabular}{lccccccc}
\hline \multirow{2}{*}{ Treatments } & \multicolumn{7}{c}{ Incubation time $(\mathrm{min})$} \\
\cline { 2 - 8 } & 0 & 30 & 60 & 90 & 120 & 150 & 180 \\
\hline $\mathrm{A}$ & 0.15 & 0.16 & 0.18 & 0.23 & 0.33 & 0.42 & 0.52 \\
\hline $\mathrm{B}$ & 0.14 & 0.14 & 0.16 & 0.22 & 0.31 & 0.39 & 0.48 \\
\hline $\mathrm{C}$ & 0.15 & 0.15 & 0.17 & 0.21 & 0.29 & 0.38 & 0.46 \\
\hline $\mathrm{D}$ & 0.14 & 0.15 & 0.17 & 0.21 & 0.29 & 0.37 & 0.46 \\
\hline $\mathrm{E}$ & 0.15 & 0.15 & 0.17 & 0.21 & 0.28 & 0.35 & 0.44
\end{tabular}

A- Yoghurt made using classic yoghurt starter (control)

B- $\quad$ Yoghurt made using ABT

C- $\quad$ Yoghurt made using ABT $+2 \%$ honey

D- $\quad$ Yoghurt made using ABT $+4 \%$ honey

E- $\quad$ Yoghurt made using ABT $+6 \%$ honey

Table 2 Effect of using of ABT culture and adding of honey to buffaloe's and cow's milk mixture on rheological properties of yoghurt

\begin{tabular}{lcccccc}
\hline \multirow{2}{*}{ Treatments } & \multirow{2}{*}{$\begin{array}{c}\text { Coagulation } \\
\text { time }(\mathrm{h})\end{array}$} & $\begin{array}{c}\text { Curd } \\
\text { tension }\end{array}$ & & \multicolumn{4}{c}{ Curd syneresis $\left(\mathrm{g} \mathrm{15} \mathrm{\textrm {g } ^ { - 1 } \text { of curd } ) *}\right.$} \\
\cline { 4 - 7 } & & $(\mathrm{g})$ & 10 & 30 & 60 & 120 \\
\cline { 4 - 7 } & 3.00 & 32.55 & 1.52 & 2.99 & 3.97 & 5.16 \\
\hline $\mathrm{A}$ & 3.20 & 32.73 & 1.76 & 3.11 & 4.14 & 5.37 \\
\hline $\mathrm{B}$ & 3.25 & 33.22 & 1.50 & 2.90 & 4.03 & 5.19 \\
\hline $\mathrm{C}$ & 3.30 & 34.68 & 1.55 & 3.03 & 4.01 & 5.23 \\
\hline $\mathrm{D}$ & 3.30 & 35.83 & 1.57 & 3.06 & 4.08 & 5.26 \\
\hline $\mathrm{E}$ & *Whey excluded $(\mathrm{g})$ from $15 \mathrm{~g}$ of curd kept at room temperature after $10,30,60$ and 120
\end{tabular}

$\min$

On the other hand, addition of honey to yoghurt (treatments C, D and E) slightly increased titratable acidity and decreased $\mathrm{pH}$ values which could be attributed to fructooligosacchrides in honey (Akalin et al., 2007). Abd El-Salam et al. (2011) cleared that the $\mathrm{pH}$ and titratable acidity of yoghurt supplemented with honey affected slightly compared with that supplemented with Bifidobacterium lactis Bb.12. On the contrary, Varga (2006) reported that honey has the ability to decrease solutions sourness. This property might serve to increase consumer acceptability to acidic products such as yogurt. Yoghurt acidity and $\mathrm{pH}$ value were affected $(\mathrm{P}<0.001)$ by treatments and the interaction of treatment $\times$ age (Tables 3 and 7). Titratable acidity values of all yoghurt treatments were acceptable according to Mehanna et al. (2003a) and Mortazavian et al. (2007) while were less than recommended by Egyptian Standards (2005). Fortification of yoghurt with honey increased TS content and the increasing rate was proportional to the honey ratios added. Total solids contents of treatments B, C, $\mathrm{D}$ and $\mathrm{E}$ after 7 days of storage were $15.60,17.11,18.51$ and $20.09 \%$, respectively. Fat and ash contents were not affected by honey incorporation with bio-yoghurt. Generally, during storage titratable acidity values of all treatments 
and control increased due to the activity of the starter culture. These results agreed with Vijayalakshmi $\boldsymbol{e t}$ al. (2010) who found that a significant increase in acidity and decrease in $\mathrm{pH}$ were noticed in low fat yoghurt during the storage period but within the permissible levels. Also, TS, fat and ash contents of all treatments increased due to the loss of moisture during storage period. Similar observation was reported by Farag et al. (2007). The statistical analysis of variance (Table 7) showed that the differences in acidity and TS values between treatments and the effect of storage time were significant $(\mathrm{P}<0.001)$.

The contents of TN, TN/DM, WSN, WSN/TN and TVFA of yoghurt as affected by using various cultures and supplementation with honey were represented in Table 4. The effect of storage time on TN content was more significant $(\mathrm{P}<0.001)$ than those of starter type or incorporation of honey. As storage period advanced, TN values of all treatments raised while they nearly remained constant between different treatments. These results are in agreement with those obtained by Akalin (1996), who reported that the type culture used in the fermentation didn't affect on the TS, TP, fat and lactose ratios of yoghurt, Bioghurt, Bifighurt and Biogarde.

Using of classic starter increased WSN content of the resulted yoghurt as compared with using ABT culture (Table 4). This may be due to proteolytic activity (endopeptidase) of $L$. delbrueckii subsp. bulgaricus which hydrolyzed casein to polypeptides then; the later was hydrolyzed to amino acids with exopeptidases produced by $S$. thermophilus (Tamime and Robinson, 1999). In all yoghurt treatments, WSN contents significantly increased during storage period. WSN content of treatment B at zero time was $0.134 \%$ and increased to $0.178 \%$ at the end of storage period. These results suggest some degradation in yoghurt protein during storage as also found by El-Shibiny et al. (1979) and Mehanna and Hefnawy (1988). Fortification of yoghurt with 2, 4 and 6\% honey (samples C, D and E) slightly increased WSN contents which may refer to the stimulation effect of fructooligosaccharides in honey on bifidobacteria (Akalin $\boldsymbol{e}$ al., 2004).

\begin{tabular}{|c|c|c|c|c|c|c|c|}
\hline Treatments & $\begin{array}{c}\text { Storage } \\
\text { period (days) }\end{array}$ & $\begin{array}{c}\text { Acidity } \\
\%\end{array}$ & $\begin{array}{c}\mathrm{pH} \\
\text { values }\end{array}$ & $\begin{array}{l}\mathrm{TS} \\
\%\end{array}$ & $\begin{array}{c}\text { Fat } \\
\%\end{array}$ & $\begin{array}{c}\text { Fat/DM } \\
\%\end{array}$ & $\begin{array}{c}\text { Ash } \\
\%\end{array}$ \\
\hline \multirow{3}{*}{ A } & Fresh & 0.79 & 4.70 & 15.47 & 5.9 & 38.14 & 0.88 \\
\hline & 7 & 1.09 & 4.42 & 15.56 & 5.9 & 37.91 & 0.91 \\
\hline & 15 & 1.25 & 4.21 & 15.70 & 6.0 & 38.22 & 0.95 \\
\hline \multirow{3}{*}{ B } & Fresh & 0.62 & 4.98 & 15.51 & 5.8 & 37.39 & 0.86 \\
\hline & 7 & 0.84 & 4.76 & 15.60 & 5.8 & 37.79 & 0.89 \\
\hline & 15 & 1.01 & 4.53 & 15.72 & 6.0 & 38.17 & 0.93 \\
\hline \multirow{3}{*}{$\mathrm{C}$} & Fresh & 0.69 & 4.87 & 16.98 & 5.9 & 34.75 & 0.89 \\
\hline & 7 & 0.90 & 4.64 & 17.11 & 6.0 & 35.07 & 0.92 \\
\hline & 15 & 1.08 & 4.46 & 17.25 & 6.1 & 35.36 & 0.92 \\
\hline \multirow{3}{*}{$\mathrm{D}$} & Fresh & 0.72 & 4.82 & 18.34 & 5.8 & 31.62 & 0.89 \\
\hline & 7 & 0.95 & 4.59 & 18.51 & 5.8 & 31.33 & 0.91 \\
\hline & 15 & 1.11 & 4.42 & 18.66 & 5.9 & 31.62 & 0.96 \\
\hline \multirow{3}{*}{$\mathrm{E}$} & Fresh & 0.73 & 4.80 & 19.91 & 5.7 & 28.63 & 0.90 \\
\hline & 7 & 0.97 & 4.56 & 20.09 & 5.8 & 28.87 & 0.92 \\
\hline & 15 & 1.11 & 4.41 & 20.28 & 5.9 & 29.09 & 0.95 \\
\hline
\end{tabular}

Total volatile fatty acids (TVFA) are taken as a measure of the degree of fat hydrolysis during storage (Table 4). As storage time increased, TVFA contents significantly $(\mathrm{P}<0.001)$ increased in all yoghurt treatments. These increases may be due to small degree of lipolysis exhibited by L. delbrueckii subsp. bulgaricus, L. acidophilus and $S$. thermophilus. Lactobacillus produces more TVFA than $S$. thermophilus. The increases of TVFA contents also may be due to oxidative deamination and decarboxylation of amino acids, which convert the amino acids into its corresponding volatile fatty acids (Tamime and Robinson, 1999). Tota volatile fatty acids of yoghurt manufactured using classic starter were very slightly higher than those of yoghurt made using ABT culture. On the other side, it could be seen that the yoghurt contained various levels of honey showed the highest increase of TVFA. In supplementary, Chick et al. (2001) mentioned that the organic acids production was enhanced when bifidobacteria were grown in the presence of honey, where various oligosaccharides found in honey may be responsible for enhancing organic acids production by bifidobacteria. Honey also contains a variety of organic acids $(0.17$ to $1.17 \%)$ such as acetic, butyric, citric, formic, gluconic, lactic, malic, pyroglutamic and succinic acids (NHB, 1996).

Table 4 Effect of using ABT culture and adding of honey on TN, WSN and TVFA contents of yoghurt

\begin{tabular}{|c|c|c|c|c|c|c|}
\hline Treatments & $\begin{array}{c}\text { Storage } \\
\text { period (days) }\end{array}$ & $\begin{array}{c}\mathrm{TN} \\
\%\end{array}$ & $\begin{array}{c}\mathrm{TN} / \mathrm{DM} \\
\%\end{array}$ & $\begin{array}{c}\text { WSN } \\
\%\end{array}$ & $\begin{array}{c}\text { WSN/TN } \\
\%\end{array}$ & TVFA* \\
\hline \multirow{3}{*}{ A } & Fresh & 0.694 & 4.49 & 0.151 & 21.76 & 6.0 \\
\hline & 7 & 0.701 & 4.50 & 0.173 & 24.68 & 6.7 \\
\hline & 15 & 0.722 & 4.60 & 0.185 & 25.62 & 7.7 \\
\hline \multirow{3}{*}{ B } & Fresh & 0.697 & 4.49 & 0.143 & 20.52 & 5.8 \\
\hline & 7 & 0.704 & 4.51 & 0.166 & 23.58 & 6.4 \\
\hline & 15 & 0.724 & 4.60 & 0.178 & 24.58 & 7.3 \\
\hline \multirow{3}{*}{$\mathrm{C}$} & Fresh & 0.695 & 4.09 & 0.146 & 21.01 & 6.0 \\
\hline & 7 & 0.703 & 4.11 & 0.168 & 23.90 & 6.6 \\
\hline & 15 & 0.719 & 4.17 & 0.180 & 25.03 & 7.6 \\
\hline \multirow{3}{*}{$\mathrm{D}$} & Fresh & 0.690 & 3.76 & 0.148 & 21.45 & 6.4 \\
\hline & 7 & 0.702 & 3.79 & 0.171 & 24.36 & 7.2 \\
\hline & 15 & 0.720 & 3.86 & 0.182 & 25.28 & 7.9 \\
\hline \multirow{3}{*}{$\mathrm{E}$} & Fresh & 0.696 & 3.49 & 0.152 & 21.84 & 6.5 \\
\hline & 7 & 0.704 & 3.50 & 0.174 & 24.71 & 7.5 \\
\hline & 15 & 0.721 & 3.55 & 0.187 & 25.94 & 8.6 \\
\hline
\end{tabular}

* expressed as $\mathrm{ml} 0.1 \mathrm{NaOH} 100 \mathrm{~g}^{-1}$ cheese

\section{Changes in bifidobacteria counts of yoghurt}

Data of counts of bifidobacteria of yogurts made using classic and ABT cultures are shown in Table 5. Counts of bifidobacteria gradually declined through refrigerated preservation of yoghurt. Loss of viability of probiotic bacteria in fermented milk was reported to be due to acid injury to the organisms (Shah, 2000). However, slight increasing of acidity ratios of honey samples (Table 3) which have negative effect on probiotic cultures as low acid tolerance, bifidobacteria count of samples contained honey were higher than those of control which may be caused by oligosaccharides presence in honey. Oligosaccharides were found to enhance the viability of starter culture as prebiotics (El-Baz and Zommara, 2007). Ustunol (2000) cleared that dairy products are the favored food for introducing lactic acid bacteria and bifidobacteria into the human digestive tract. The purpose for doing this is to improve the microbial balance of the intestine. Bifidobacteria, however, are fastidious microorganisms. Keeping their numbers large enough to be meaningful can be a challenge to food manufacturers. Honey contains a small percentage of oligosaccharides that could serve as a food source for these beneficial bacteria, thereby, making honey a "prebiotic" for the "probiotic" dairy food. Mehanna et al. (2003b) and Sanz et al. (2005) found that as a prebiotic, honey contains carbohydrates called oligosaccharides, which may improve gastrointestinal health by stimulating the growth of good bacteria in the colon. Honey has been shown to enhance growth, activity of bifidobacteria in fermented dairy food. Abd- ElSalam et al. (2011) stated that supplementation of yoghurt with honey and $B$. lactis improved growth of bacterial starter.

However, a little decrease of bifidobacteria numbers was observed during storage period. The recommended level of bifidobacteria is of $10^{6}$ or $10^{7} \mathrm{cfu} \mathrm{g}^{-1}$ as a probiotic, while, this number was exceeded for all treatments of bio-yoghurt 
around $10^{6} \mathrm{cfu} \mathrm{g}^{-1}$ until the end of storage period. After 15 days of storage period, bifidobacteria counts of treatments B, C, D and E were 1.7, 2.3, 2.7 and $3.5 \times 10^{6}$ cfu $\mathrm{g}^{-1}$, respectively. Ouwehand and Salminen (1998) stated that in order to exhibit positive health effects of probiotics, they have to deliver in certain numbers. As a guide, the International Dairy Federation (IDF) suggested a minimum of $10^{7} \mathrm{cfu}$ of probiotics $\mathrm{g}^{-1}$ product should be alive at the time of consumption. Similar results and recommendations were obtained by Moreno $\boldsymbol{e} t$ al. (2006) and Jayamanne and Adams (2006).

\section{Changes in sensory evaluation of yoghurt during refrigerated storage}

Organoleptic properties evaluation is an important indicator of potential consumer preferences. The popularity of yoghurt as a food component depends mainly on its sensory characteristics and addition of different flavours to yoghurt has been found to increase options for consumers and helps in marketing yoghur and retaining consumer interests (Routray and Mishra, 2011). Impact of culture type and incorporation of honey on sensory quality of yoghurt is given in Table 6. Organoleptic profiles of yoghurt made using of classic starter were found to be comparable to those of yoghurt samples manufactured by ABT culture at zero time and during storage period. Total scores of sensory evaluation for samples A and B at the end of storage period were 89 and 88 respectively. Ayad et al. (2010) stated that using bifidus culture with yoghurt culture in yoghurt like products manufacturing enhanced body and texture of all treatments.

Because of the sweet taste of honey, which is preferable for many consumers, it was not surprising that the flavour evaluation test of yoghurt supplemented with different honey concentrations gained the highest scores. Addition of honey not only improved yoghurt flavour, but also body and texture. All honey yoghur samples were considered acceptable. Treatment E (6\% honey) received the highest total score, which may be attributed to the suitable firmness body and sweet taste. Confirmation for these results, it could be seen from Table 2 that treatment $\mathrm{E}$ had the longest fermentation time $(3.30 \mathrm{~h})$ which may resulted in greater firmness (Damin et al., 2006). Our results are in agreement with those of Riazi and Ziar (2012) who stated that as for sensory properties, the product formulation with the highest concentration of honey (that is, $10 \% \mathrm{w} / \mathrm{v}$ ) was too sweet and was evaluated as strong in honey flavour. However, the yogurt samples containing $5 \%(\mathrm{w} / \mathrm{v})$ of honey were found to have optimum sweetness. The points allocated for colour, body-texture and taste showed that an increase in honey content brought about an improvement in the texture, flavour and aroma of the products $(\mathrm{P}<0.05)$. Also, they cleared that the addition of honey had a good effect on sensory properties of fermented milk with bifidobacteria $(\mathrm{P}<0.05)$, and a particular noticeable yogurt or probiotic flavour was found. All the samples gave a good total impression, were medium sour and did not have any marked off-flavour during the storage period. None of the sweetened fermented milks were judged to be weak.

Table 5 Effect of using ABT culture and adding of honey on bifidobacteria count (cfu g ${ }^{-1}$ ) of yoghurt

\begin{tabular}{lcc}
\hline Treatments & Storage period (days) & Bifidobacteria $\left(\times 10^{6}\right)$ \\
\hline & Fresh & - \\
A & 7 & - \\
& 15 & - \\
\hline & Fresh & 2.8 \\
B & 7 & 2.3 \\
& 15 & 1.7 \\
\hline & Fresh & 3.3 \\
C & 7 & 2.8 \\
& 15 & 2.3 \\
\hline & Fresh & 3.9 \\
D & 7 & 3.4 \\
& 15 & 2.7 \\
\hline & Fresh & 4.7 \\
E & 7 & 4.0 \\
& 15 & 3.5 \\
\hline
\end{tabular}

Table 6 Effect of using ABT culture and adding of honey on organoleptic properties of yoghurt

\begin{tabular}{|c|c|c|c|c|c|}
\hline Treatments & $\begin{array}{c}\text { Storage } \\
\text { period (days) }\end{array}$ & $\begin{array}{c}\text { Color \& } \\
\text { appearance } \\
(15)\end{array}$ & $\begin{array}{c}\text { Body \& } \\
\text { texture } \\
(35)\end{array}$ & $\begin{array}{c}\text { Flavour } \\
(50)\end{array}$ & $\begin{array}{l}\text { Total } \\
(100)\end{array}$ \\
\hline \multirow{3}{*}{ A } & Fresh & 13 & 31 & 45 & 89 \\
\hline & 7 & 13 & 31 & 45 & 89 \\
\hline & 15 & 12 & 29 & 42 & 83 \\
\hline \multirow{3}{*}{ B } & Fresh & 13 & 31 & 44 & 88 \\
\hline & 7 & 13 & 31 & 44 & 88 \\
\hline & 15 & 12 & 28 & 42 & 87 \\
\hline \multirow{3}{*}{$\mathrm{C}$} & Fresh & 13 & 33 & 47 & 93 \\
\hline & 7 & 12 & 33 & 47 & 92 \\
\hline & 15 & 12 & 31 & 46 & 89 \\
\hline \multirow{3}{*}{$\mathrm{D}$} & Fresh & 13 & 34 & 48 & 95 \\
\hline & 7 & 13 & 34 & 48 & 95 \\
\hline & 15 & 12 & 32 & 46 & 90 \\
\hline \multirow{3}{*}{$\mathrm{E}$} & Fresh & 13 & 34 & 48 & 95 \\
\hline & 7 & 12 & 34 & 48 & 94 \\
\hline & 15 & 12 & 33 & 47 & 92 \\
\hline
\end{tabular}

\section{CONCLUSIONS}

Addition of honey increased the total solids content of the product thereby increasing its total food value. Bifidobacteria were greatly activated by mixing of honey with yoghurt milk which main that honey could be utilized as sweeter and prebiotic in bio-yoghurt production. The result of the organoleptic properties of yoghurt cleared that there was no difference in color and appearance while there were differences in the body, texture and flavour. Incorporation of honey highly improved the sensory evaluation scores of the resulted yoghurt.

\section{REFERENCES}

ABD EL-SALAM, B.A., ZAYAN, A.F., MAILAM, M.A. 2011. Effect of fortification with honey and Bifidobacterium strain on the characteristics of yoghurt. Egyptian J. Dairy Sci., 39, 65-74.

AKALIN, A.S. 1996. L (+), D (-) Lactic acid contents and aroma profiles in Bioghurt, Bifighurt, Biogarde in comparison with yoghurt. Egyptian J. Dairy Sci., 24, 227-234.

AKALIN, A.S., FENDERYA, S., AKBULUT, N. 2004. Viability and activity of bifidobacteria in yoghurt containing fructoooligosaccharide during refrigerated storage. Int. J. of Food Sci. and Tech. 39, 613-621. http://dx.doi:10.1111/j.13652621.2004.00829.x

AKALIN, A.S., GONC, S., UNAL, G., FENDERYA, S. 2007. Effects of fructoooligo-saccharide and whey protein concentrate on the viability of starter culture in reduced-fat probiotic yoghurt during storage. J. Food Sci., 72, 222-227. http://dx.doi:10.1111/j.1750-3841.2007.00436.x
AOAC., 2000. Official Methods of Analysis. Association of Official Analytical Chemists. $17^{\text {th }}$ ed, Washington, DC, USA.

AYAD, H.E., DARWISH, A.M.G., DARWISH, S.M., EL-SODA, M. 2010 Production of novel functional yoghurt-like products. Egyptian J. Dairy Sci., 38 , 183-199.

BOGDANOV, S., JURENDIC, T., SIEBER, R., GALLMANN, P. 2008. Honey for nutrition and health: a review. J. the American College of Nutrition, 27, 677689. http://dx.doi.org/10.1080/07315724.2008.10719745

CHANDRASEKHARA, M.R., BHAGAWAN, R.K., SWAMINATHAN, M., SUBRAHMANYAN, V. 1957. The use of mammalian milk and processed milk foods in the feeding of infants. Indian J. Child. Health, 6, 701-710.

CHICK, H., SHIN, H.S., USTUNOL, Z. 2001. Growth and acid production by lactic acid bacteria and bifidobacteria grown in skim milk containing honey. $J$ Food Sci., 66,478-486. http://dx.doi.org/10.1111/j.1365-2621.2001.tb16134.x

DAMIN, M.R., MINOWA, E., ALCANTARA, M.R., OLIVEIRA, M. 2006 Chemical and viability changes during fermentation and cold storage of fermented milk manufactured using yogurt and probiotic bacteria. XIIIth World Congress of Food Science and Technology "FOOD IS LIFE", Nantes, France, September, 17-21. http://dx.doi.org/10.1051/iufost:20060635

DAMIN, M.R., MINOWA, E., ALCANTARA, M.R., OLIVEIRA, M.N. 2008 Effect of cold storage on culture viability and some rheological properties of fermented milk prepared with yoghurt and probiotic bacteria. J. Texture Studies, 39, 40-55. http://dx.doi.org/10.1111/j.1745-4603.2007.00129.x

DE JONG, L. 1978. The influence of the moisture content on the consistency and protein breakdown of cheese. Neth. Milk Dairy J. 32, 1-8. 
DINAKAR, P., MISTRY, V.V. (1994). Growth and viability of Bifidobacterium bifidum in Cheddar cheese. J. Dairy Sci., 77, 2854-2864. http://dx.doi.org/10.3168/jds.s0022-0302(94)77225-8

DUNCAN, D.B. 1955. Multiple Range and Multiple F-test. Biometrics, 11, 1- 42. http://dx.doi.org/10.2307/3001478

EGYPTIAN STANDARDS FOR ZABADY, 2005. ES:1000/2005. Ministry of Industry and Technological Development. Egypt.

EL-BAZ, A.M., ZOMMARA, M.A. 2007. Characteristics of carbonated stirred yoghurt-bifidum milk fortified with honey and vitamin C. Egyptian J. Dairy Sci., $35,45-51$

EL-NEMER, T.M., AWAD, S.A., ALI, A.H. 2003. Increasing of probiotic and therapeutic action in Karish cheese using Tolue balsam extract. Egyptian J. Food Sci. 31, 213-220.

El-Shazly, A.A., El-Tahra, M.A. Ammar, Ismail, M.M., Eid, M.Z. 2008. Effect of cold storage and mixing various lactations of buffaloe's and cow's milk on some properties of yoghurt. J. Agric., Sci., Mansoura Univ., 33 (7):5141-5151.

EL-SHIBINY, S., GHITA, I., ABDOU, S.M. 1979. The use of skim milk powder in the manufacture of yoghurt. Egyptian J. Dairy Sci., 5, 109-115.

EREJUWA, O.O., GURTU, S., SULAIMAN, S.A., WAHAB, M.S.A. SIRAJUDEEN, K.N.S., SALLEH, M.S.M. 2010. Hypoglycemic and antioxidant effects of honey supplementation in streptozotocininduced diabetic rats. Int. J. for Vitamin and Nutrition Res., 80, 74-82. http://dx.doi.org/10.1024/03009831/a000008

FARAG, S. I. EL-SONBATY, A. H. HUSSEIN, S. A. FARAG, A.F. SHAHINE, A.M. 2007. Effect of substituting added skim milk powder (SMP) with wheat germ (WG) on the quality of goat's milk yoghurt and fermented camel's milk drink. $10^{\text {th }}$ Egyptian Conference of Dairy Science and Technology. pp. 315-336.

GHASHM, A.A., OTHMAN, N.H., KHATTAK, M.N., ISMAIL, N.M., SAINI, R. 2010. Antiproliferative effect of Tualang honey on oral squamous cell carcinoma and osteosarcoma cell lines. BMC Complementary and Alternative Medicine, 10, 1-8.

HASSAN, A.N., IPSEN, R., JANZEN, T., QVIST, K.B. 2003. Microstructure and rheology of yoghurt made with cultures differing only in their ability to produce Exopolysaccharides. J. of Dairy Sci. 86, 1632 1638. http://dx.doi.org/10.3168/jds.s0022-0302(03)73748-5

HUGHES, D.B., HOOVER., D.G. 1991. Bifidobacteia: Their potential for use in American Dairy Products. Food Technol. 45, 74-80.

JAYAMANNE, V.S., ADAMS, M.R. 2006. Determination of survival, identity and stress resistance of probiotic bifidobacteria in bio-yoghurts. Letters in Appl. Microb. 42, 189-194. http://dx.doi.org/10.1111/j.1472-765x.2006.01843.x

KEHAGIAS, C., KOULOURIS, S., ARKOUDELOS, J.S., SAMONA, A. 2006

Viability and bio-chemical activity of bifidobacteria in association with yoghurt starter cultures in Bifidus milk and bio-yoghurt during storage at $4^{\circ} \mathrm{C}$. Egyptian J. Dairy Sci., 34, 151-158.

KOSIKOWSKI, F.V. 1978. Cheese and Fermented Milk Food, $3^{\text {rd }}$ ed. New York, USA: Cornell University, Ithaca.

LING, E.R. 1963. A Text - Book of Dairy Chemistry. Vol. 2, Practical, 3rd ed. Champan and Hall, London, England.

MATTILA-SANDHOLM， T., MYLLARINEN， P., CRITTENDEN， R. MOGENSEN, G., FONDEN, R., SAARELA, M. 2002. Technological challenges for future probiotic foods. Int. Dairy J. 12, 173182. http://dx.doi.org/10.1016/s0958-6946(01)00099-1

MEHANNA, N.M., MEHANNA, A.S. 1989. Studies on the use of stabilizer for improving some properties of cow's milk yoghurt. Egyptian J. Dairy Sci., 17, 289.

MEHANNA, N.M., HEFNAWY, S.A. 1988. Effect of thiocyanate-lactoperioxide -hydrogen peroxide system on the manufacture and properties of yoghurt. Egyptian J. Dairy Sci., 16, 55-63.

MEHANNA, N.S, SALEM, M.M.E, ZAKY, W.M, EL- KHALEK, A.B.A 2003a. Viability of probiotic bacteria in functional fermented milk. Ann. of Agri. Sci., 48, 691-702.

MEHANNA, N.SH., IBRAHIM, G.H., GAD EL-RAB, D.A. 2003b. The influence of inulin addition on the quality of functional fermented milk. Minufiya J. of Agric. Rese. 28, 906-912.

MORENO, Y., COLLADO, M.C., FERRUS, M.A., COBO, J.M., HEMANDEZ E., HEMANDEZ, M. 2006. Viability assessment of lactic acid bacteria in commercial dairy products stored at $4^{\circ} \mathrm{C}$ using LIVE/ DEAD ${ }^{\circledR}$ Bac-LightTM staining and conventional plate counts. Int. J. of Food Sci. and Tech. 41, 275-280 http://dx.doi.org/10.1111/j.1365-2621.2005.01060.x

MORTAZAVIAN, A.M., EHSANI, M.R., MOUSAVI, S.M., REZAEI, K. SOHRABVANDI, S., REINHEIMER, J.A. 2007. Effect of refrigerated storage temperature on the viability of probiotic micro-organisms in yogurt. Int. J. Dairy Tech. 60, 123-127. http://dx.doi.org/10.1111/j.1471-0307.2007.00306.x

MURAD, H.A., SADEK, Z.I., FATHY, F.A. 1998. Production of bifidus Karish cheese. Deutsch lebensmittel Rundschau. 94, 409-415.

NHB, 1996. "NATIONAL HONEY BOARD" Non-peroxide antibacterial activity in some New Zealand honey. J. Apicul Res. 27, 62-69.
OUWEHAND, A.C., SALMINEN, S.I. 1998. The health effect of cultured milk products with viable and non-viable bacteria. Int. Dairy J., 8, 749-758 http://dx.doi.org/10.1016/s0958-6946(98)00114-9

OZBAS, Z.Y., AYTAC, S.A. 1995. Behaviour of Yersinia enterocolitica and Aeromonas hydrophila in yogurt made with probiotic bacteria- Bifidobacterium infantis and Lactobacillus acidophilus. Milchwissenschaft. 50, 626-629.

PARMAR, R. 2003. Incorporation of acid whey powders in probiotic yoghurt. M Sc. Thesis, Major in Biological Sciences, Specialization in Dairy, South Dakota State University, U.S.A.

POORANI, A., SUBRAMONIAN, B.S., ELANGO, A., PUGHAZHENTHI, T.R., DHANALAKSHMI, B. 2012. Synbiotic bifido milk powder in weaned piglets: Effect on growth, hematology and intestinal histology. Egyptian J. Dairy Sci., 40, 91-97.

REDDY, G.V. 1983. Antitumor activity of yogurt components. J. Food Prot. 46, 8-11.

RIAZI, A., ZIAR, H. 2012. Effect of honey and starter culture on growth, acidification, sensory properties and bifidobacteria cell counts in fermented skimmed milk. African J. of Microbiology Res. 6, 486-498.

ROUTRAY, W., MISHRA, H.N. 2011. Scientific and technical aspects of yoghurt aroma and taste; a review. Compr Rev Food Sci Fd Safety.10, 208 220. http://dx.doi.org/10.1111/j.1541-4337.2011.00151.x

SACCARO, D.M., TAMIME, A.Y., PILLEGGI, A.O.P.S, OLIVEIRA, M.N. 2009. The viability of three probiotic organisms grown with yoghurt starter cultures during storage for 21 days at $4^{\circ} \mathrm{C}$. Int. J. of Dairy Tech. 62, 397 404. http://dx.doi.org/10.1111/i.1471-0307.2009.00497.x

SAMONA, A., ROBINSON, R.K. 1994. Effect of yogurt cultures on the survival of bifidobacteria in fermented milks. J. Soc. Dairy Technol. 47, 58 60. http://dx.doi.org/10.1111/i.1471-0307.1994.tb01273.x

SANZ, M.L., POLEMIS, N., MORALES, V., CORZO, N., DVAKOULARAKOU, A., GIBSON, G.R. 2005. In vitro investigation of potential prebiotic activity of honey oligosaccharides. J. Agri. and Food Che., 11 2914-2921. http://dx.doi.org/10.1021/jf0500684

SAS 1991. SAS User's guide: statistics. SAS Inst, Inc, Cary, NC.

SHAH, N. P. 2000. Probiotic bacteria: Selective enumeration and survival in dairy foods. J. Dairy Sci. 83, 894-907. http://dx.doi.org/10.3168/jds.s00220302(00)74953-8

SHAH, N.P. 1993. Effectiveness of dairy products in alleviation of lactose intolerance. Food Aust. 45, 262-265.

SHIHATA, A., SHAH. N.P. 2002. Influence of addition of proteolytic strains of Lactobacillus delbrueckii subsp. bulgaricus to commercial ABT starter cultures on texture of yogurt, exopolysaccharide production and survival of bacteria. Int. Dairy J. 12, 765-772. http://dx.doi.org/10.1016/s0958-6946(02)00071-7

TAMIME, A.Y., ROBINSON, R.K. 1999. Yoghurt Science and Technology, $2^{\text {nd }}$ ed., CRC Press LLC, Washington, DC. http://dx.doi.org/10.1111/j.1471 0307.1999.tb02857.x

USTUNOL, Z. 2000. Honey's effect on growth of bifidobacteria. Rept. National Honey Board, Longmont, Colo., USA.

VARGA, L. 2006. Effect of acacia (Robinia pseudo acacia L.) honey on the characteristic microflora of yoghurt during refrigerated storage. Shor $\begin{array}{lllll}\text { communication. Int. J. Food Microbiol. } & 108,272\end{array}$ 275. http://dx.doi.org/10.1016/j.ijfoodmicro.2005.11.014

VIJAYALAKSHMI, R., NARESHKUMAR, C., DHANALAKSHMI, B. 2010. Storage studies of cereal based low fat fruit yogurt. Egyptian J. Dairy Sci., 38, $53-62$ 
